\title{
Psychological Stress and Educational Effect during Bedside Practice on Psychiatric Nursing
}

\author{
Rieko KAWAMOTO' and Masako KANAYAMA ${ }^{2}$ \\ 'Division of Nursing, School of Health Sciences, University of Occupational and Environmental \\ Health, Japan. Yahatanishi-ku, Kitakyushu 807-8555, Japan \\ ${ }^{2}$ The School of Allied Health Science, Yamaguchi University. Ube 755-8554, Japan
}

Abstract: The aim of this study is to analyze the educational effect and the factors of psychological stress of bedside practice on psychiatric nursing. The subjects studied were 76 nursing students in a nursing college. They answered a questionnaire and underwent the STAI-test before and after the periods of their bedside practice during psychiatric nursing. The results obtained were as follows; 1 . The awareness structure of the nursing students was composed of 6 factors, that is, anxiety and detestation factor, understanding and acceptance factor, social alienation factor, denial factor, affirmation factor and closed society factor. 2. The changes in their awareness were observed before and after the periods of bedside practice. 3. The STAI-test showed that the nursing students frequently complained of anxiety before the bedside practice because they had only studied about the psychoses. 4. The nursing students who had strong anxiety also showed a deep fear and detestation. 5. Some nursing students who had had a deep anxiety before the bedside practice found their anxiety reduced because of the direct contact with psychotic patients. 6. Although the nursing students had psychological stress, they were also interested in the psychiatric nursing.

Key words: psychiatric nursing, educational effect, awareness to psychotic patients, anxiety, psychological stress.

(Received 17 November 1997, accepted 9 April 1998)

\section{Introduction}

Bedside practice is one of the most important curriculums in nursing education. Bedside practice in the psychiatric nursing field is said to cause various kinds of psychological stress to the students because they have prejudices against psychotic patients and difficulties in communicating with them. We have been studying the awareness of nursing students to psychiatric diseases and have concluded that their awareness is well related to the change in awareness structure and anxiety $[1-4]$. The relationship 
between anxiety regarding bedside practice and personality of the nursing students has been studied [5]. In this study, we also analyze the changes of awareness structure and anxiety in order to evaluate their psychological stress. Furthermore, the effect of stress on the interests of nursing students in the bedside practice of psychiatric nursing is discussed.

\section{Subjects and Methods}

The study subjects were 76 nursing students in a nursing college. All subjects gave his or her informed consent. They answered the questionnaire and underwent the STAI-test before and after the periods of their bedside practice in psychiatric nursing. The questionnaire was composed of 23 items concerning "awareness of psychiatric disease", which had been obtained from research using description methods. The answers to the questionnaire were quantified from 1 to 5 according to the degree of agreement to each item. Before the bedside practice, the intensity of the anxiety and its reasons were discussed with the students. The items of anxiety were answered from 1 to 5 according to the degree of anxiety level which the subjects felt. After the bedside practice, the students were questioned again by another questionnaire about their interest in psychiatric nursing. The STAI-test used in this study was drawn up by Spielburger and translated by Kimura et al.

\section{Results}

The results of the questionnaire were composed of 23 items, analyzed by factor analysis (Varimax rotation), and the factor scores were compared before and after the bedside practice. The relation between awareness structure and anxiety was also studied using the STAI-test (Nippon University Edition) before and after the bedside practice.

1. Results of the awareness study

The awareness structure of the nursing students was composed of 6 factors, that is, anxiety and detestation factor, understanding and acceptance factor, social alienation factor, denial factor, affirmation factor and closed society factor (Table 1). 2. Change in the average score of each item before and after the periods of bedside practice

The changes of their awareness were observed before and after the periods of the bedside practice in psychiatric nursing. The items which showed significant differences were 10 in number. The shift from "not agree" to "agree" was observed in four items, that is, "Psychotic patients are difficult to access," "Psychotic patients are uncanny," "Mental hospital is gloomy" and "Psychotic 
Table 1. Results of factor analysis

\begin{tabular}{|c|c|c|c|c|c|c|c|c|}
\hline No & Itcms & $\mathrm{fl}$ & $\mathrm{f} 2$ & $\mathrm{f} 3$ & f4 & 85 & 16 & \\
\hline 5 & Psychotic patients are uncanny & 0.79 & -0.08 & 0.00 & 0.15 & -0.06 & -0.06 & \multirow{4}{*}{$\begin{array}{l}\text { Anxicty and detestation } \\
\text { factor }\end{array}$} \\
\hline 1 & Psychotic patients are difficult to access & 0.78 & -0.14 & 0.07 & -0.06 & -0.12 & 0.10 & \\
\hline 10 & Mental hospital is gloomy & 0.78 & -0.05 & 0.02 & -0.04 & -0.11 & 0.22 & \\
\hline 13 & Psychotic patients are fearsome & 0.78 & -0.04 & 0.03 & 0.20 & 0.01 & -0.06 & \\
\hline 14 & $\begin{array}{l}\text { Understanding of psychiatric discases is } \\
\text { important }\end{array}$ & -0.07 & 0.80 & 0.05 & 0.07 & 0.10 & -0.01 & \multirow{4}{*}{$\begin{array}{l}\text { Understanding and } \\
\text { acceptance factor }\end{array}$} \\
\hline 23 & Psychotic paticnts necd human relationships & -0.01 & 0.80 & 0.03 & -0.11 & 0.06 & 0.09 & \\
\hline 20 & $\begin{array}{l}\text { Psychiatric discascs are disorders of the } \\
\text { cmotions }\end{array}$ & 0.03 & 0.55 & 0.20 & -0.24 & 0.14 & 0.34 & \\
\hline 6 & To support psychotic paticnts is necessary & -0.10 & 0.42 & 0.34 & 0.09 & 0.02 & -0.08 & \\
\hline 17 & Psychiartric discases hinder marriage & 0.18 & -0.03 & 0.73 & -0.02 & -0.04 & -0.15 & \multirow{6}{*}{ Social alicnation factor } \\
\hline 18 & Families of Psychotic patients have a big burden & -0.18 & 0.24 & 0.55 & -0.03 & -0.05 & 0.11 & \\
\hline 19 & Psychiatric diseases are hereditary & 0.07 & 0.00 & 0.53 & 0.27 & -0.08 & -0.47 & \\
\hline 15 & Psychiatric diseases are anxious diseases & 0.03 & -0.15 & 0.51 & -0.03 & 0.37 & 0.36 & \\
\hline 4 & Psychotic paticnts are pitiful & 0.23 & 0.15 & 0.46 & 0.04 & 0.04 & 0.11 & \\
\hline 2 & $\begin{array}{l}\text { Psychiatric diseases are difficult ones to treat } \\
\text { and care for }\end{array}$ & -0.14 & 0.22 & 0.36 & 0.09 & 0.33 & 0.18 & \\
\hline 11 & Psychotic paticnts should be isolated & 0.02 & -0.02 & -0.05 & 0.78 & 0.11 & -0.04 & \multirow{4}{*}{ Denial factor } \\
\hline 16 & Psychotic patients have intelligence disorders & -0.06 & -0.06 & -0.04 & 0.58 & -0.39 & 0.31 & \\
\hline 8 & Psychotic patients are dangerous & 0.34 & -0.10 & 0.33 & 0.52 & 0.00 & 0.06 & \\
\hline 21 & Psychotic patients are unpredictable & 0.37 & 0.12 & 0.10 & 0.47 & 0.00 & 0.05 & \\
\hline 7 & Psychiatric discases are intimate diseases & -0.08 & 0.10 & -0.03 & -0.01 & 0.80 & -0.15 & \multirow{3}{*}{ Affirmation factor } \\
\hline 12 & $\begin{array}{l}\text { Psychiatric discases are caused by social and } \\
\text { domestic problems }\end{array}$ & -0.07 & 0.14 & 0.02 & -0.04 & 0.63 & 0.35 & \\
\hline 22 & Psychotic patients are innocent & -0.31 & 0.46 & -0.05 & 0.14 & 0.40 & -0.05 & \\
\hline 9 & $\begin{array}{l}\text { Psychotic patients are awkward in human } \\
\text { relationships }\end{array}$ & 0.20 & 0.09 & 0.05 & 0.19 & -0.02 & 0.74 & \multirow[t]{2}{*}{ Closed socicty factor } \\
\hline 3 & A psychotic patient is confined to his/her world & 0.36 & 0.25 & 0.13 & 0.20 & 0.23 & 0.34 & \\
\hline
\end{tabular}

patients are fearsome" (Fig. 1).

3. The relation between factor scores and STAI scores

The STAI score concerning the state of anxiety before bedside practice was significantly higher than that after the bedside practice (Fig. 2). From the correlation between scores of the extracted 6 factors and the STAI scores, significant correlations between the first factor and state of anxiety $(\mathrm{r}=0.377, P<$ $0.01)$ and between the first factor and traits of anxiety $(r=0.222, P<0.05)$ were observed. It is suggested that the students with high scores concerning anxiety also had high scores in the first factor (Tables 2, 3).

4. Intensity of anxiety and its reasons before the bedside practice

The average degree of anxiety levels was 3.6 (SD: 0.9 ). The type of anxiety which was answered most frequently was whether the subject can communicate. 


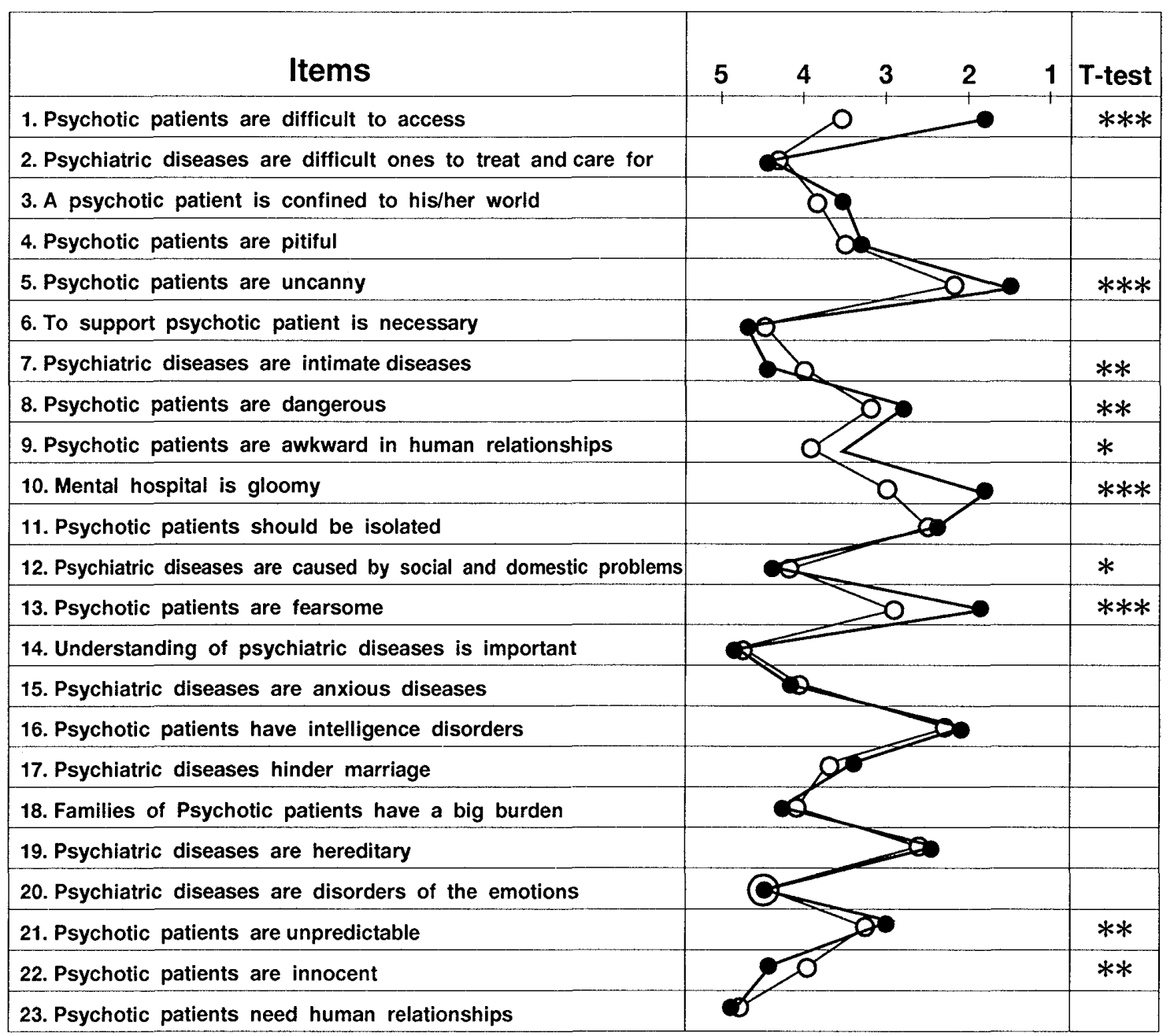

Fig. 1. Average score of each item (before/after).

$\bigcirc-\bigcirc$ before, - after, ${ }^{*} P<0.05,{ }^{* *} P<0.01, \quad{ }^{* * *} P<0.001, \quad(\mathrm{~N}=76)$

Also questions regarding, severity and type of diseases were answered.

More than half of the subjects (54.4\%) felt anxiety. On the other hand, most of the students $(85.5 \%)$ were interested in psychiatric nursing. 5. Psychological and educational effects after the bedside practice

As shown in Table 4, 34.2\% of the students strongly felt psychological stress. Almost every student (97.1\%) recognized the value of the practice, but $23.2 \%$ of the students answered that they now have a strong interest in psychiatric nursing which we think is due to the good results of their bedside practice. Only 4 subjects did not have any interest in this type of nursing. 


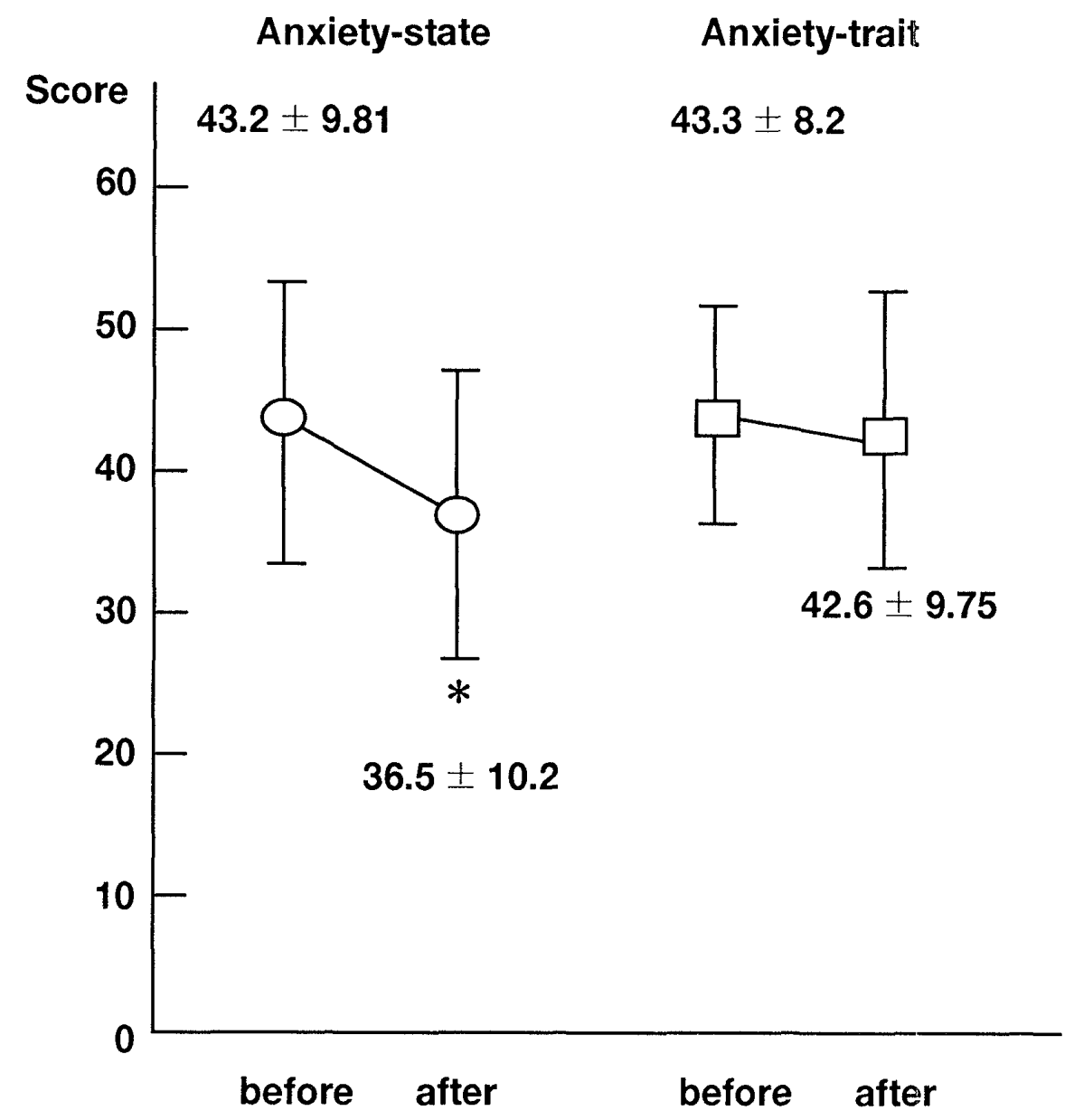

Fig. 2. Score of STAI-test (before/after).

${ }^{*} P<0.01 \quad(\mathrm{~N}=76)$

Table 2. Comparison of the factor scores of the nursing students before and after bedside practice

\begin{tabular}{|c|c|c|c|c|c|c|c|}
\hline & $\mathrm{N}$ & $\begin{array}{l}\text { Anxicty and } \\
\text { detcstation } \\
\text { factor }(\mathrm{fl})\end{array}$ & $\begin{array}{l}\text { Understanding } \\
\text { and acceptance } \\
\text { factor (f2) }\end{array}$ & $\begin{array}{l}\text { Social } \\
\text { aliention } \\
\text { factor (B) }\end{array}$ & $\begin{array}{l}\text { Denial } \\
\text { factor (f4) }\end{array}$ & $\begin{array}{l}\text { Affirmation } \\
\text { factor (f5) }\end{array}$ & $\begin{array}{l}\text { Closcd socicty } \\
\text { factor (f6) }\end{array}$ \\
\hline $\begin{array}{l}\text { Before bedside } \\
\text { practice }\end{array}$ & 76 & $0.664 \pm 0.746$ & $-0.100 \pm 1.125$ & $-0.006 \pm 0.967$ & $0.016 \pm 0.900$ & $-0.212 \pm 1.054$ & $0.122 \pm 0.899$ \\
\hline $\begin{array}{l}\text { Afcr bedside } \\
\text { practicc }\end{array}$ & 76 & $-0.664 \pm 0.749$ & $0.100 \pm 0.845$ & $0.006 \pm 1.032$ & $-0.016 \pm 1.090$ & $0.212 \pm 0.894$ & $-0.112 \pm 1.080$ \\
\hline$l$-valuc & & $10.96^{*}$ & 1.25 & 0.78 & 0.12 & $2.68^{*}$ & 1.39 \\
\hline
\end{tabular}

\section{Discussion}

1. Anxiety and Stress

The large part of awareness structure of nursing students to psychiatric diseases changed in accordance to their acceptance of psychotic patients. Their anxiety was caused by their awareness structures, especially fear, the detestation factor and closed society factor. Their anxiety was classified into state of anxiety 
Table 3. Correlation between STAI and items of questionnaire

\begin{tabular}{|c|c|c|c|c|}
\hline STAI & $\begin{array}{l}\text { Before bedside practice } \\
\text { Items of questionnaire }\end{array}$ & C.C. & $\begin{array}{l}\text { After bedside practice } \\
\text { Items of questionnaire }\end{array}$ & C.C. \\
\hline \multirow[t]{2}{*}{ State of anxicty } & $\begin{array}{l}\text { A psychotic paticnt is confined to } \\
\text { his/her world }\end{array}$ & $0.26^{*}$ & Psychotic paticnts arc uncanny & $0.33^{* *}$ \\
\hline & $\begin{array}{l}\text { Psychiatric descases are disorders } \\
\text { of the cmotions }\end{array}$ & $0.32^{* *}$ & Psychotic paticnts are fcarsome & $0.40^{* *}$ \\
\hline \multirow[t]{5}{*}{ Traits of anxiety } & $\begin{array}{l}\text { A psychotic patient is confined to } \\
\text { his/her world }\end{array}$ & $0.24^{*}$ & Psychotic paticnts are uncanny & $0.28^{*}$ \\
\hline & Psychotic patients are uncanny & $0.24^{*}$ & Psychotic patients are dangerous & $0.26^{*}$ \\
\hline & & & $\begin{array}{l}\text { Psychotic paticnts are awkward } \\
\text { in human rclationship }\end{array}$ & $0.24^{*}$ \\
\hline & & & Mental hospital is gloomy & $0.24^{*}$ \\
\hline & & & Psychotic paticnts are fearsome & $0.32^{* *}$ \\
\hline
\end{tabular}

C.C.: Coefficient of correlation,

*: $P<0.05,{ }^{* *}: P<0.01$

Table 4. Educational effect and psychological stress duc to the bedside practice in psychiatric nursing

\begin{tabular}{|c|c|c|}
\hline Content & Answer & $\mathrm{N}(\%)$ \\
\hline \multirow[t]{3}{*}{ Lcarning through practice } & Yes & $74(97.4)$ \\
\hline & Not either & $2 \quad(2.9)$ \\
\hline & No & $0 \quad(0.0)$ \\
\hline \multirow[t]{4}{*}{ Interests in psychiatric nursing } & Strong & $18(23.2)$ \\
\hline & Modcratc & $53(69.9)$ \\
\hline & Wcak & $1(1.4)$ \\
\hline & Nonc & $4 \quad(5.8)$ \\
\hline \multirow[t]{3}{*}{ Psychological stress during bedside practice } & Self-awarencss to stress & $26(34.2)$ \\
\hline & Fatigue caused by the tension & $29(38.2)$ \\
\hline & Nonc & $21(27.6)$ \\
\hline
\end{tabular}

and traits of anxiety using Spielburger's method. The state of anxiety is said to be a transient unstable state and a reaction which occurs against a definite stimulus. It can be measured as a function of the stimulus by physiologic means. The measurement values concerning state of anxiety indicate the results of the reaction to stressful circumstances and fluctuate ceaselessly. On the other hand, the measurement values concerning the traits of anxiety value should be stable and consistent. According to Spielburger's theory, the bedside practice is suspected to cause a psychological stress in nursing students because the state of anxiety was high before the bedside practice. From the results of awareness structure and state of anxiety, the content of the psychological stress is seen as images of fear, detestation of psychiatric diseases and a strong tendency to be affected by these factors. 
2. The effect of the psychological stress on the interests in psychiatric nursing The students felt psychological stress before the bedside practice because their state of anxiety value was high. One of the main psychological stress reasons is whether they can communicate with the patients well.

In the questionnaire study after the bedside practice, about $70 \%$ of the students felt stress, more or less. However, fear and prejudice was lessened after communicating with the patients. As a conclusion, the bedside practice in psychiatric nursing did not have a negative affect on the meaning of the practice and interests in psychiatric nursing even though it caused psychological stress.

(A part of this article was presented at the International Congress of Health Psychology in Tokyo in 1993.)

\section{References}

1. Kawamoto R, Kanayama M, Tanaka M et al (1989): The fundamental of the teaching method of the psychiatric nursing practice in a nursing college. Nippon Oyou Shinrigaku Gakkaishi (Appl Psycol) 56: 64 (in Japanese)

2. Kanayama M, Kawamoto R et al (1992): The Consciousness to the of the Students in a Nursing College (3)-In Relation with C.A.S. Test-. Nippon Kango Kenkyu Gakkai Zasshi (Journal of Japanese Society of Nursing Research) 15: 56-62 (in Japanese with English abstract)

3. Kanayama M, Tanaka M, Kawamoto $\mathrm{R}$ et al (1993): The attitude toward the mental disordered of the students in a nursing college (4)--In relation with C.A.S. Test and STAI-. Nippon Kango Kenkyu Gakkai Zasshi (Journal of Japanese Society of Nursing Research 16 : 21-28 (in Japanese with English abstract)

4. Kanayama M, Tanaka M, Kawamoto R et al (1994): The change of the attitude toward the mental disordered of the students in a nursing college by the psychiatric nursing practice-In comparison before and after the lecture and practice--. Nippon Kango Kenkyu Gakkai Zasshi (Journal of Japanese Society of Nursing Research) 17: 69-78 (in Japanese with English abstract)

5. Kanayama M, Kawamoto $\mathrm{R}$ et al (1995): The relation between the change of the attitude toward the mental disordered and the anxiety of the students in a nursing college on the psychiatric nursing practice. -In relation with STAI and C.A.S.Test-. Nippon Kango Kenkyu Gakkai Zasshi (Journal of Japanese Society of Nursing Research) 18: 7-16 (in Japanese with English abstract)

6. Tanaka Y, Hokari C, Fukuda A et al (1994): Longitudinal changes in negative self-awareness in interpersonal relationships at the time of adolescence. Shinri Rinshogaku Kenkyu (Journal of Japanese Clinical Psychology) 12: 121-131 (in Japanese with English abstract)

7. Tadatsu S, Manabe Y et al (1997): A study on changes in the view of the mental disorders - A survey on images of the mental disorders in the nursing students-. Kagawa Ika Daiguku Kangogaku Zasshi (Nursing Journal of Kagawa Medical University) 1: 102-114 (in Japanese with English abstract) 


\section{精神科実習における心理的ストレスと教育効果}

川本利恵子 ${ }^{1}$, 金山 正子 $^{2}$

'産業医科大学産業保健学部 第一看護学講座 ${ }^{2}$ 山口人大学医療技術短期大学部 看護学科

要旨：本研究は, 精袖科実習前後の看護学生の意識構造と不安の変化を測定し, 心理的ス トレスの程度とその内容を把握し，そのストレスが教育効果に与える影響を検討す る目的で行った。某短期大学看護学科 3 年生 76 名を対象に，精神科実習前後に質 問紙調查とSTAI テストを行った。質問紙の因子分析を行った結果，看護学生の意 識構造は恐怖・嫌要因子，理解・受容因子，社会的踈外因子，否定的因子，肯定的 因子，閉鎖的因子の 6 因子で構成されていた。また，実習前後の学生の意識構造に 変化が示された，STAI テストでは実習前の状態不安が高かった．意識構造と不安に ついて検討した結果，特に恐怖・嫌悪因子，閉鎖的因子，つまり患者への偏見によっ て不安が引き起こされたことが示された。この不安は実習に対する心理的ストレス となっていた。精神病に対する恐怖・嫌悪・閉鎖性などのイメージがもたらす不安 であり，コミュニケーションが上手くとれるかを心配していた。しかし，精神科看 護への興味，関心は実習後も維持できていた。

J UOEH（産業医大誌）20（2）：127－134（1998) 